PRODUCTION

ENGINEERING ARCHIVES
2014, Vol. 3, No 2, pp 18-21

ISSN 2353-5156

ISSN 2353-7779 (print version)

(online version)

Article history: Received: 13.04.2014

\title{
Analysis of the modernity and effectiveness of chosen machines in the processing of high-molecular materials
}

\author{
Marek Krynke ${ }^{1}$, Krzysztof Knop ${ }^{2}$, Krzysztof Mielczarek ${ }^{3}$ \\ ${ }^{1}$ Institute of Production Engineering, Faculty of Management, Czestochowa University of Technology, Armii Krajowej 19B, 42-201 \\ Czestochowa, Poland, e-mail: krynke@ zim.pcz.pl \\ ${ }^{2}$ Institute of Production Engineering, Faculty of Management, Czestochowa University of Technology, Armii Krajowej 19B, 42-201 \\ Czestochowa, Poland, e-mail: kknop@poczta.fm \\ ${ }^{3}$ Institute of Production Engineering, Faculty of Management, Czestochowa University of Technology, Armii Krajowej 19B, 42-201 \\ Czestochowa, Poland, e-mail: k.mielczarek@wp.pl
}

Abstract. In the article enterprise acting in the business of processing plastics was researched. In the enterprise is realizes mainly mass production. The main factor that decides about the reliability of applied technologies there are used machines. As a result of analysis a modernity level of sub-assemblies for two machines was determined (injections moulding machine and extrusion machine). Analysis of the machines effectiveness based on chosen TPM coefficients was also undertaken. It allowed the assessment of the working time of these machines.

Key words - efficiency, TPM, OEE, modernity, the ABC technology

\section{Introduction}

The Machinery and devices are the basis for the functioning of the production system of each company. They decide on the level of quality of manufactured products and the success of the company in light of the customer requirements. The right approach is important to the operation of machinery, and their running maintenance. Repair and maintenance service system of machinery and equipment is a component of the operating system of a company (SELEJDAK J. BORKOWSKI S. 2009). In order to improve the system it is necessary to analyze the current status and the conditions in which they are exploited in the machine during production. Analysis by having relevant data allows you to focus on strategies for optimization and process improvement in the operation of the maintenance and repair of machines and conclude further proposals in this regard (ULEWICZ R. 2013).

In this chapter improving the operating conditions of the extruder and injection molding machines is outlined in the production of plastic parts by evaluating the level of the machine's modernity and to determine its effectiveness coefficients. 


\section{An assessment of the machines subas- semblies modernity on the basis of ABC technology method}

Based on the ABC technology method a modernity of extruders and injection molding machines were evaluated. Using the division into components rated the level of modernity using a 5 - point Parker scale (SELEJDAK J. BORKOWSKI S. 2009). The results of evaluations of modernity level of both machines is presented in the table 1 and presented graphically in the form of graphs contained in Figure 1. The majority of the basic subassembly of extrusion machine W45Tk these are straight parts. They were assessed as 2 and 3 according to the Parker scale. Applying wellverified technologies is appearing in $40 \%$ of parts in the basic subassembly.

Table 1. The Rating of elements modernity in the W45-Tk extruder and CL Tk3330 injection

\begin{tabular}{|c|c|c|c|}
\hline \multicolumn{4}{|c|}{ Assessment of the level of machinery components parts modernity } \\
\hline \multicolumn{2}{|c|}{ extruder } & \multicolumn{2}{|c|}{ injection } \\
\hline \multicolumn{4}{|l|}{ Basic component parts A } \\
\hline 1. The control system & Level 3 & 1. The control system & Level 4 \\
\hline 2. Console & Level 3 & 2. Console & Level 3 \\
\hline 3. Programming system & Level 2 & 3. Programming system & Level 4 \\
\hline 4. Fixing system & Level 3 & 4. Fixing system & Level 3 \\
\hline 5. Plasticizing & Level 3 & 5. Assembly pressing & Level 3 \\
\hline 6. Auger diameter & Level 3 & 6. Auger diameter & Level 4 \\
\hline 7. Performance & Level 4 & 7. Clamping force & Level 3 \\
\hline 8. Injection time & Level 4 & 8. Injection time & Level 4 \\
\hline 9. Cooling time & Level 4 & 9. Cooling time & Level 4 \\
\hline 10. Plastic Tray & Level 4 & 10. Plastic Tray & Level 3 \\
\hline \multicolumn{4}{|c|}{ Subassembly supporting components B } \\
\hline 1. Closure assembly & Level 3 & 1. Closure assembly & Level 3 \\
\hline $\begin{array}{l}\text { 2. Trunk system of } \\
\text { waste }\end{array}$ & Level 4 & 2. Injection grammage & Level 3 \\
\hline 3. Engine Power & Level 3 & 3. Power Heater & Level 3 \\
\hline 4. Pneumatic system & Level 4 & 4. Hydraulics & Level 4 \\
\hline \multicolumn{4}{|c|}{ Parts of secondary components $\mathrm{C}$} \\
\hline $\begin{array}{l}\text { 1. Construction equ- } \\
\text { ipment (enclosure) }\end{array}$ & Level 2 & $\begin{array}{l}\text { 1. Construction equ- } \\
\text { ipment (enclosure) }\end{array}$ & Level 2 \\
\hline 2. Cooling System & Level 4 & 2. Cooling System & Level 3 \\
\hline 3. Lubrication System & Level 3 & 3. Lubrication System & Level 2 \\
\hline $\begin{array}{l}\text { 4. The transport of } \\
\text { waste }\end{array}$ & Level 3 & 4. The amount of mold & Level 3 \\
\hline $\begin{array}{l}\text { 5. Guides the finished } \\
\text { product }\end{array}$ & Level 4 & $\begin{array}{l}\text { 5. Number of spheres } \\
\text { heating }\end{array}$ & Level 3 \\
\hline 6. Injection Pressure & Level 3 & 6. Injection Pressure & Level 3 \\
\hline $\begin{array}{l}\text { 7. Pneumatic control } \\
\text { system }\end{array}$ & Level 4 & & \\
\hline 8. Layout notch & Level 4 & & \\
\hline
\end{tabular}

Source: own study.

In the group of the auxiliary subassembly one can observe more modern parts than in the subassembly baseline. There is a balance of modern parts and parts using mastered technology. Half parts were assessed at 4 and a half at level 3 on a Parker's scale.

The secondary subassembly has a complex structure of modern parts. The largest percent are parts of technologically modern. $13 \%$ used standard parts in terms of technology for technology assessment level 2, but less than half of the applied parts rated at level 4, which shows a fairly high technological level of parts included in the subassembly of the secondary of the extruder The W45-Tk.

Drawings $1 \mathrm{~g}$ and $1 \mathrm{~h}$ show a summary list of the parts used in subassemblies of the extruder is a W45$\mathrm{Tk}$ and the structure ratings level of their modernity in a Parker's scale.
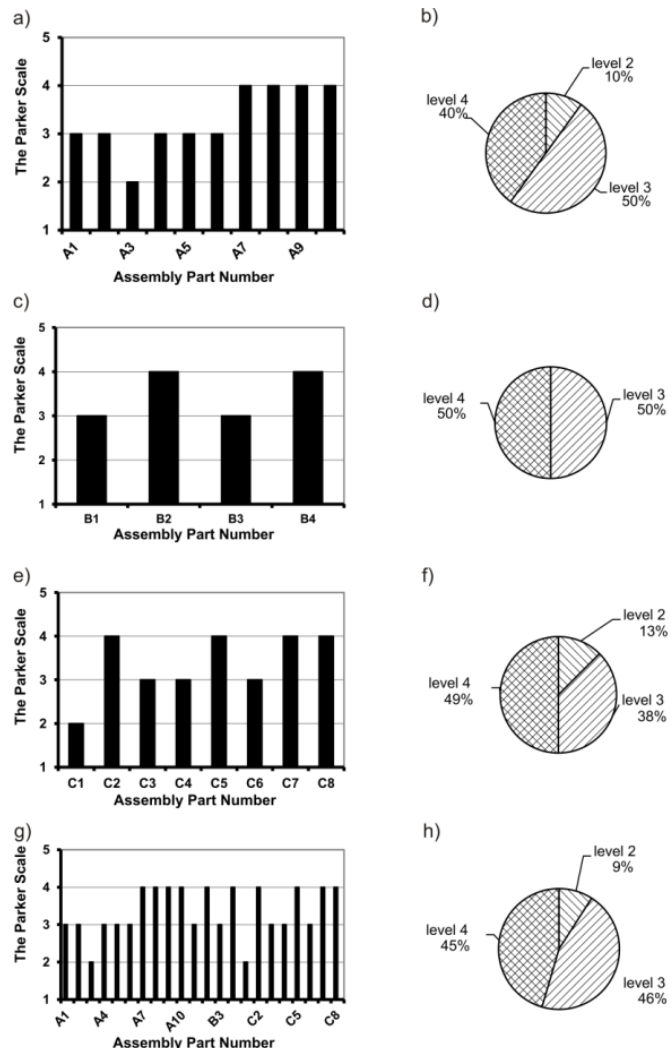

Fig. 1. The modernity of the W45-Tk extruder parts according to the Parker's scale and structure of the ratings:

$a), b)$ the basic component, $c$ ), d) an auxiliary component, e), $f$ ) of the secondary component, $g$ ), h) extruder's basic subassemblies, auxiliary and secondary.

Source: own study.

Analysis of part of the extruder subassemblies in 45-Tk modernity shows that in general, the components parts are classified as level 4 and 3. This shows that a fairly high degree of machinery and technology 
was modern. Only $9 \%$ of the parts are standard components and not modern.

Figure 2 shows a graphic representation of subassemblies parts of injection molding machines modernity assessment.

a)
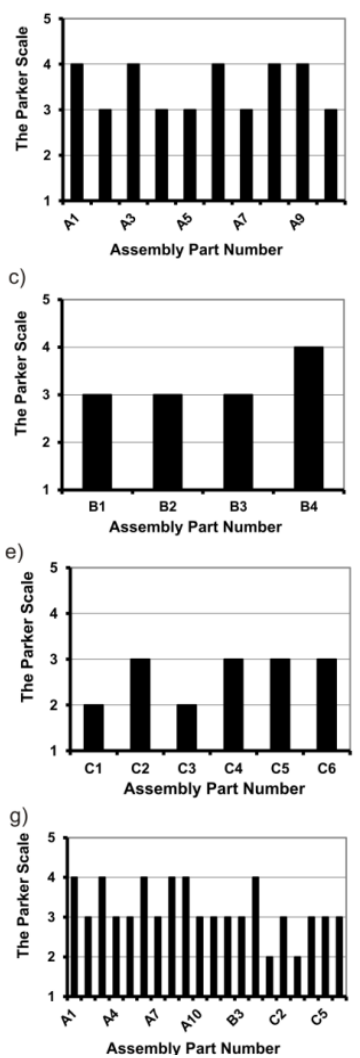

Fig. 2. The construction modernity of the DK injection molding machine according to the Parker's scale 3330, and according to the level of ratings $A, B$ ) of the basic component parts of, $c), d$ ) an auxiliary component, $e$ ), $f$ ) of the secondary component, $g$ ), h) extruder's basic subassemblies, auxiliary and the secondary.

Source: own study.

Among the part used in the subassembly of the basic half is on level 3 and 4 . This proves the application to a large extent that there is more modern technology.

The structure of modernity ratings demonstrates that in auxiliary injection molding machine subassembly there are few modern parts. Mainly these are elements developed based on standard technologies, wellknown for years. Only $25 \%$ of them are parts of assessed at level 4 of Parker's scale, which indicates a more modern construction used in these items. The secondary subassembly of injection molding machine is characterized by a small amount of modern compo- nent parts. Rather, they are the components produced by standard technology. The components of the secondary subassembly injection molding machine DK 3330 were rated at level 2 and 3, which indicates the standard components used in the composition of this subassembly.

The analysis of the parts of subassemblies: primary, auxiliary and secondary injection molding machine shows a diversity of modern components. Most of them are standard parts rated at level 2 and 3, while $30 \%$ of these parts using more modern technology as evidenced by the rating level on the Parker's scale modernity at level4.

\section{The evaluation of the operation of machines on the basis of factors TPM}

The Total Productivity Management TPM is a program of preventive maintenance of machines in the factory. The main goal of TPM is minimized to zero any failures, defects, and other factors affecting the decrease in productivity of the manufacturing process and increasing the reliability of the machines (BORKOWSKI S., KRYNKA M., RUTKOWSKI W. 2011). Implementation of the TPM enables you to: improve the degree of efficiency of machines, reduce downtime, increase awareness of employees and their commitment to work, extend the competences of employees, the share of operators in routines for handling machines, etc. (SALAMON S. 2006, K. MIELCZAREK, S. BORKOWSKI 2008). Implementation of TPM allows effective use of existing resources. The measure allows assessment of the efficient use of machinery in the machine park OEE (Overall Equipment Effectivess), which is calculated from the formula:

$$
O E E=W E \cdot W W \cdot W J \cdot 100 \%
$$

where: $W E$ - Operating factor, $W W-$ yield factor, $W J$ - quality factor.

The expected value of $O E E$ is a min. $60 \%$. OEE factor enables the assessment of the efficiency and functioning of the machines.

As part of the analysis the effectiveness of DK 3300 injection molding machines were assessed and W45-Tk extruders. Tests were carried out for 30 days of continuous operation of both machines working 
from 1 to 30 July. Figure 3 shows the average values of the TPM coefficients.$$
\text { a) }
$$

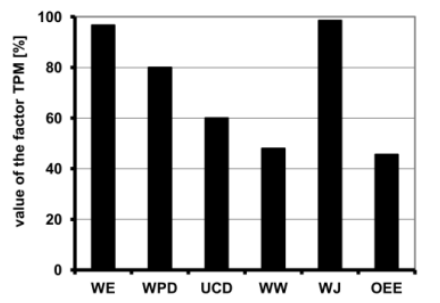

factors TPM

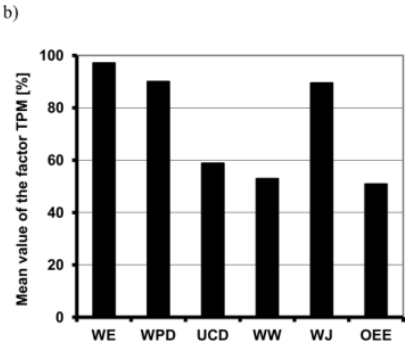

factors TPM
Fig. 3. Summary of the average values of the TPM coefficients for the DK 3330 injection (a) and the W45-Tk extruder (b) for the 30 - day period test.

Source: own study.

It turns out that the highest average of the coefficients of the TPM characterized by $W J$ quality factors, which for injection is $98.5 \%$ and the WE operation factor with an average of $96.7 \%$. The WPD factor of speed was the same for the entire study period and amounted to $80 \%$. The same value throughout the period also had a useful duration of $U C D$, which was $60 \%$ and the $W W$ yield factor with a value of $48 \%$. The average overall efficiency of the injection molding machine in the period was $45.6 \%$.

The highest average value during the period of extruder W45-Tk showed a WE factor operation at the level of $97.12 \%$ and the $U C D$ useful operating time, which throughout the period was at the same level of $90 \%$. The average value of the quality factor was $89.53 \%$. A useful operating time showed the same value throughout the period of $58.82 \%$. The coefficient of performance during the 30 days of the machine remained at $52.94 \%$. The overall average efficiency extruder ranged from $50.85 \%$.

\section{Summary}

The study has been subject to a company operating in the plastics processing industry. Due to the implementation of mass production enterprise the main factor is the used machines.

As a result of analysis, the level of modern parts of two selected assemblies of machines (injection molding and extruder) working in the company was determined. The analysis parts of the extruder assemblies indicates that the high degree of modern machinery and technology used. Only $9 \%$ of the parts are stand- ard components and not modern. Analysis of the parts and assemblies: primary, auxiliary and secondary injection shows a diversity of modern components. Most of them are standard parts, while $30 \%$ of these parts of the application are modern technology.

Times obtained from observing the work of injection molding machines and extruders were also analysed. The overall efficiency $O E E$ of the injection molding machine in the period was $45.6 \%$, while $50.8 \%$ of the extruder. Global research indicates that the average rate of $O E E$ in manufacturing plants is around $60 \%$. However, $O E E$ should be treated as an internal indicator - a number that allows to estimate the improvement or deterioration of the situation compared to another period on the same machine or production line.

In order to improve the overall efficiency of the tested machines of the analysed plant should focus primarily on improving the efficiency factor, which is a combination of factors: $W P D$ speed of operation and the useful operating time $U C D$.

\section{Literature}

1. Borkowski S., KrYnKe M., RUtKOWski W. 2011. Evaluation of the Effectiveness of Operation of Machines Based on Factors TPM and PAMCO. Chapter 11. Conditions of Machines Operating and Quality Products. Monography. Editing and Scientific Elaboration Stanisław Borkowski, Jacek Selejdak. Wyd.LigaPress. Lviv. s.125-136.

2. K. MielcZAREK, S. BorKOWSKI 2008. Practise of Calculation TPM Coefficients. Chapter 20. In: Quality Improvement and Machines Exploitation. S. Borkowski, J. Kliber (ed.). Publishing and Press Association of Universities Russia. Saint-Petersburg.

3. SALAMON S. 2006. Wskaźniki w kompleksowym utrzymaniu maszyn (TPM). Rozdział 13. W: Efektywność eksploatacji maszyn $i$ zdolność jakościowa procesu. BORKOWSKI S., HRUBEC J. (red.). Wydawnictwo Instytut Organizacji i Zarządzania w Przemyśle „ORGMASZ”. Warszawa.

4. SElEJdAK J., BORKOWSKI S. 2009. Parker Scale Utilization in Modernity of Machine Evaluation. [w]: Kvalita a Spol'ahlivost Technickych Systemov. 14 Medzinarodna Vedecka Konferencia, Nitra, s. 117-119.

5. SELEJDAK J., BORKOWSKI S. 2009. TPM Coefficients as Efficiency Measures of Machine in Car Tyre Production. Journal of Machine Manufacturing Vol. 49 Iss. E3-E5 Special Triple Edition, s. 134-137.

6. ULEWICZ R. 2013. Effectiveness assessment of functioning of quality assurance system. Production Engineering Archives 1 (2013). 